Military Technical College

Kobry El-Kobbah,

Cairo, Egypt

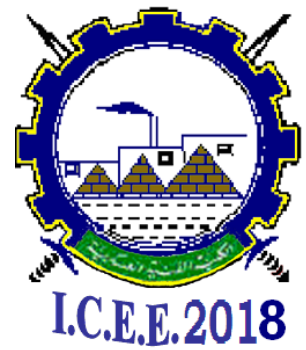

EPC-1 $9^{\text {th }}$ International Conference on

Chemical \& Environmental

Engineering

3-5 April 2018

\title{
Application of Remote Sensing data (GSMaP) to Flash Flood Modeling in an Arid Environment, Egypt
}

\author{
Adel Bakheet ${ }^{1}$, Ahmed Sefelnasr ${ }^{2}$
}

\begin{abstract}
Rainfall-runoff modeling tackled in this research is a challenging aspect in hydrology. Arid regions are vulnerable against flash floods disaster. Unfortunately, there is often a lack of data on hydrological processes in arid regions. This limits the ability to understand the flash flood process. The present study aims to use Remote Sensing data (GSMaP) to overcome shortage of data. Geographic Information System (GIS) and Remote Sensing have played an essential role in data collection and hydrological modeling. Two wadis have been selected as a case study for the application, which are Wadi El-Assiuti and Wadi Qena. Geographic Information System (GIS) and Remote Sensing have been used to delineate the drainage system and watershed from the Digital Elevation Model (DEM). Due to the scarcity of observational data, computations are carried out where Remote Sensing data (GSMaP_MVK+) was used to evaluate the precipitation rate over different wadis as well as to simulate several flash flood events. GSMaP can be used as input data in hydrological models to predict flash floods. This paper presents the current and future trends of Remote Sensing data (GSMaP) in hydrological modeling. The primary focus of this paper is the data availability and further opportunities for hydrological modeling development.
\end{abstract}

Keywords:

Flash Flood, (GSMaP_MVK+), (GIS), Remote Sensing, Egypt.

1-Chemistry administration, M sc. "Environmental Protection"\& Water Resources Management: Address- Assiut bakheet_adel@yahoo.com

2- Associate professor of Hydrogeology, Geology Department, Assiut University

Address- Assiut ahmed.sefelnasr@science.au.edu.eg 
Military Technical College

Kobry El-Kobbah, Cairo, Egypt

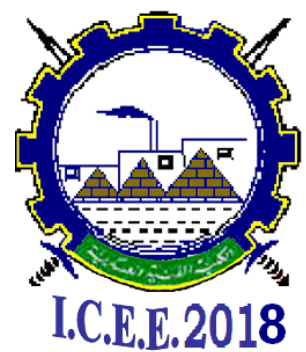

$9^{\text {th }}$ International Conference on

Chemical \& Environmental

Engineering

3-5 April 2018

\section{Introduction}

Rainfall is the most vital input data for various hydrologic models. Its duration, intensity, distribution and return periods are major influences. Obtaining accurate and reliable Rainfall data is thus very important for local, regional and global hydrologic prediction and water resources management. Due to the lack of adequate network of monitoring stations, rainfall data and their analysis are limited in most of arid regions. Traditionally, the acquisition of precipitation data is often limited to ground-based observations (using rain gauges and/or ground-based weather radars) although these surface-based observations usually suffer from low spatial coverage, especially in developing regions where ground-based observations are rare or even unavailable. Recently, a number of global high resolution satellite-based precipitation products have been available, such as the Global Satellite Mapping of Precipitation (GSMaP), the Tropical Rainfall Measuring Mission (TRMM) Multi-satellite Precipitation Analysis products (TMPA), the Precipitation Estimation from Remotely Sensed Information using Artificial Neural Networks (PERSIANN), the National Oceanic and Atmospheric Administration Climate Prediction Center morphing technique product (CMORPH), the PERSIANN-Cloud Classification System estimation (PERSIANN-CCS), the Naval Research Laboratory Global Blended-Statistical Precipitation Analysis data (NRL-Blend), and so on. These satellite precipitation products have provided global high-temporal and spatial resolution rainfall maps.

However, satellite precipitation products need be evaluated against in situ observations and then calibrated to various hydrological models before fullscale deployment and application to daily and sub-daily hydrological operations. These studies emphasized that satellite precipitation products have certain accuracy and great potential for hydrologic applications. It is important to note, however, that different types of satellite precipitation data might have variable accuracy and thus distinct hydrological utility in different regions. This plays a role in determining which precipitation product is most optimal for certain regions. This task proved to be difficult because of the inconsistency among satellite observations and retrieval algorithms as well. How to identify these optimal satellite products and how to achieve the best possible streamflow simulation forced by a suite of satellite precipitation products has been a challenge.

Despite the critical importance of water in arid and semi-arid areas, hydrological data have historically been severely limited. So, the simulations using satellite rainfall products are a novel method to improve the stream flow simulations or predictions, especially for the data-poor and ungauged basins. Wadi El-Assiuti and Wadi Qena in Egypt were selected as case study to apply (GSMaP) and (Hydro-BEAM) model .The modeling approach is a powerful tool to simulate the surface water process in the rainfall- 


\author{
Military Technical College \\ Kobry El-Kobbah, \\ Cairo, Egypt
}

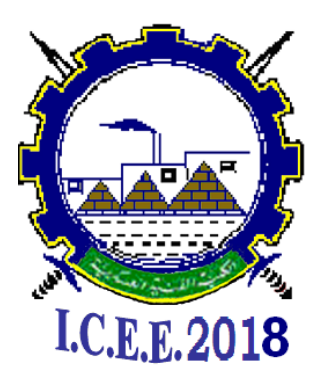

$9^{\text {th }}$ International Conference on

Chemical \& Environmental

Engineering

3-5 April 2018

runoff analysis. As satellite data, infrared and microwave satellite products, such as the Global Satellite Mapping of Precipitation (GSMaP) as a combination of multiple precipitation satellite data, could be used to derive estimates of large scale precipitation over a global area [1]. The GSMaP rain product is based on using four satellite microwave radiometers combined with Geo Infrared radiometer data to produce 0.1 degree spatial resolution [2].

Comprehensive details about the GSMaP_MVK ground validation program, algorithms and data processing were provided by [3]. In addition, GSMaP_MVK was verified from January through December 2004 in Japan to determine whether monthly data, daily data and 3 hourly data matched rain gauge data [4]. Moreover, other groups studied different locations to validate GSMaP_MVK data. According [5] [6] [7] [8] , the GSMaP_MVK data could detect a precipitation occurrence with the same trend as rain gauge data, but the precipitation amount generally underestimated in some cases.GSMaP_MVK had serious underestimation of rainfall amount compared with other precipitation satellite[9]. For these reasons, improving the GSMaP_MVK data verification result is important, especially when heavy rainfall occurs.

The current study thus focused on two aspects. First, the most widely used global highresolution satellite precipitation products (GSMaP_MVK+), and (GSMaP_NRT), $1 \mathrm{~h}$ and $0.1^{\circ}$ ) were introduced, demonstrated and used in predict rain data of the Wadi ElAssiuti and Wadi Qena in Egypt. Second, their stream flow simulation results were comprehensively evaluated using the Hydro-BEAM (Hydrological Basin Environmental Assessment Model) during the period of 2003-2010 in Wadi El-Assiuti and Wadi Qena in Egypt. The advantages of the simulations from GSMaP satellite precipitation products were capitalized.

\section{Materials and Method}

\subsection{The target wadi basins}

The selected wadi basins are wadi El-Assiuti and wadi Qena as shown in fig.1. which are located in the Eastern Desert of Egypt. wadi El-Assiuti is located between Long: $32^{\circ} 30^{\prime} \mathrm{E}$ \& $31^{\circ} 12^{\prime} \mathrm{W}$ and Lat: $27^{\circ} 48^{\prime} \mathrm{N} \& 27^{\circ} 00^{\prime} \mathrm{S}$, and it is considered as sub-basin of the Nile River Basin. The total area of Wadi El-Assiuti Catchment is $7293 \mathrm{~km}^{2}$, the perimeter is $496.91 \mathrm{Km}$ and the length of the main channel is $165.09 \mathrm{~km}$. Most of its area is a desert except some part of urbanization, and very small areas of agricultures which are closed to Assiut city along the Nile River Basin. So studying this area is important due to the propagation of populations and consequently the need of water resources for agricultural, domestic and manufactory purposes. wadi qena is located between Long: $32^{\circ} 30^{\prime} \mathrm{E} \&$ $31^{\circ} 12^{\prime} \mathrm{W}$ and Lat: $27^{\circ} 48^{\prime} \mathrm{N} \& 27^{\circ} 00^{\prime} \mathrm{S}$. Wadi Qena basin is considered a sub-basin of the whole River Nile basin. Wadi Qena is located in the middle of the Egyptian Eastern 

Military Technical College
Kobry El-Kobbah, Cairo, Egypt

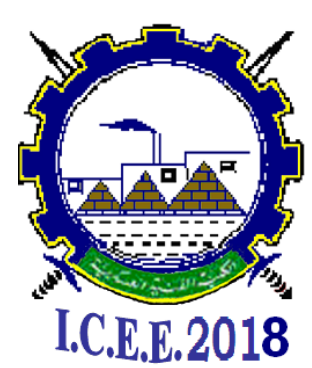

$9^{\text {th }}$ International Conference on

Chemical \& Environmental

Engineering

3-5 April 2018

Desert. Its total area is approximately equal to $16,000 \mathrm{~km}^{2}$, the perimeter is $730 \mathrm{Km}$ and the length of the main channel is $421 \mathrm{~km}$ Wadi El-Assiuti catchment has undergone a number of improvements over the past centuries, where many of the past studies were applied and many of projects established there due to its importance. Furthermore, it is a good choice for application of the Wadi modeling simulation because its characteristics of the arid conditions for example its drainage system is ephemeral streams and the rainfall is very rare in space and time. Presently, the establishment of new town, which will be in the near future crowded by populations and consequently the importance of hydrological modeling for water resources management and flood threat control, is so crucial. Wadi Qena is one of the most promising areas for national development. Wadi Qena water resources are very vital for its habitants and development projects there.

\subsection{GSMaP Data}

GSMaP was initiated by the Japan Science and Technology Agency (JST) in 2002 and has been promoted by the Japan Aerospace Exploration Agency (JAXA) Precipitation Measuring Mission (PMM) science team since 2007 to produce a global precipitation product with high temporal and spatial resolution [10]. Moreover, the data set produced by GSMaP product can be downloaded from their website: http://sharaku.eorc.jaxa.jp/GSMaP crest/html/data.html. The standard version of the GSMaP data sets includes GSMaP_TMI (retrieved from TRMM/TMI algorithm), GSMaP_MWR (retrieved from six space borne microwave radiometers), GSMaP_ MWR+ (retrieved from six space borne microwave radiometers with AMSU-B product), GSMaP_MVK (retrieved from MWR GEO IR combined algorithm), GSMaP_MVK+ (retrieved from MWR GEO IR combined algorithm with AMSU-B product) and other rainfall estimates from passive microwave radiometer [11].

The GSMaP rainfall product used here for input data to Hydro-BEAM is GSMaP_MVK product version 5.222. This product is the combination of low earth orbit multi satellite microwave radiometer data and infrared radiometer (IR) on geostationary (Geo) orbit. The available microwave sensors are SSM/I (Special Sensor Micro- wave/Imager), TMI (TRMM Microwave Imager), and AMSR-E (Advanced Microwave Scanning Radiometer for EOS). Whereas, the IR data sets used in the current version of the system are from the CPC (Climate Prediction Centre). The algorithm to regain surface precipitation rate based on the [9] was conducted in this product. The brightness temperature at microwave frequencies as the main input of GSMaP_MVK system was converted into precipitation data [10]. The combination technique to produce 0.10 in latitude and longitude and 1 hour resolution with the domain covering $60^{\circ} \mathrm{N}$ to $60^{\circ} \mathrm{S}$ was obtained using a morphing technique based on an infrared cloud moving vector and Kalman Filter technique 

Military Technical College
Kobry El-Kobbah, Cairo, Egypt

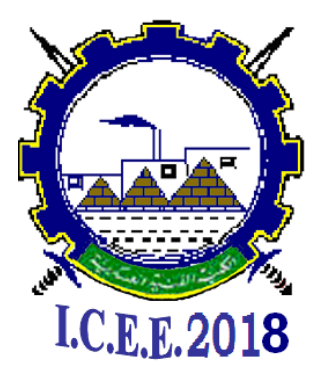

$9^{\text {th }}$ International Conference on

Chemical \& Environmental Engineering

3-5 April 2018

[10].GSMaP_MVK version 5 is available from March 2000 until December 2010. The rain rate daily data of GSMaP_MVK from 2003 to 2010 were downloaded and then GSMaP_MVK was processed by using FORTRAN 90 language [12].Detail about Characteristic of GSMaP_MVK Product was shown in Table 1.

\subsection{Model components.}

Modeling processes and programming were implemented using programming language of FORTRAN (FORTRAN 90, Intel visual FORTRAN composer X E 2011). HydroBEAM is a collection of about 50 computer programs(codes) written in the FORTRAN 90 language [12].Hydro-BEAM consists mainly of three main modeling parts; climatic modeling, watershed modeling and the main program modeling.

Hydro-BEAM is one of the distributed hydrological models to assess not only dynamic behavior of water and material but also ecological environment with regard to a water cycle in a river basin [13] [14]. This model can be widely applied to analyze spatiotemporal changes of evapotranspiration, snowfall/snowmelt, discharge, groundwater, water temperature, water quality, ecology, and so on. In general cases of calculating them, an analytical approach has to be appropriately selected on the bases of research aims, targets and conditions on data and time. Hydro-BEAM can be feasible with various builtin ways of flexible modeling [15].

Hydro-BEAM was first developed by [16] as a tool to assist in simulating long-term fluctuations in water quantity and quality in rivers through an understanding of the hydrological processes that occur within a watershed. It has since been used in a pioneering work on comparative hydrology, where a methodology for assessing the similarity between watersheds was proposed [17], to investigate sediment transport processes in the large watershed of the Yellow River, China [18] and to investigate pesticide levels in rivers and their effects on hormone levels in fish [19].

Hydro-BEAM is a multilayer hydrological model, four layers (A-D); A-Layer is composed of the surface and soil surface layer. Kinematic wave model and Manning equation are used to estimate the surface runoff and roughness coefficient in each mesh of the watershed basin. B-D-Layers are subsurface layers, which are evaluated using linear storage model, with the assumption of that the flow in each of B and $\mathrm{C}$ layers toward the river, but D-layer is considered as groundwater storage as shown in figure 2.

Rainfall-runoff modeling is the process of transforming a rainfall hyetograph into a runoff hydrograph. This can be achieved through the use of data-driven or statistical mathematical techniques, through developing physical descriptions of the rainfall-runoff process, or through various combinations of these approaches.

Hydro-BEAM has been chosen for simulation the surface runoff in the arid area due to its flexibility of application to accomplish many purposes of hydrological simulation. The 

Military Technical College
Kobry El-Kobbah, Cairo, Egypt

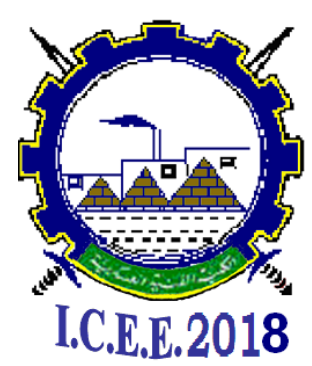

$9^{\text {th }}$ International Conference on

Chemical \& Environmental Engineering

3-5 April 2018

most important merit of Hydro-BEAM is that its ability for simulation of the monthly, daily and hourly discharge at every mesh.

Hydro-BEAM is one of the distributed runoff models developed by Kojiri's Laboratory. The watershed is modeled as a uniform array of multi-layered mesh cells, each mesh containing information regarding surface land use characteristics, ground surface slope direction, runoff, and the presence/absence of a channel. Initial and transmission losses are evaluated as subroutine model in Hydro-BEAM in this study, as crucial resource for the subsurface water in such areas.

The watershed to be investigated is divided into an array of unit mesh cells. A mesh cell can be arranged as a combination of a surface layer and several subsurface layers. The following description considers Hydro-BEAM calibrated with four subsurface layers, labeled A, B, C and D. A-Layer is calibrated using Kinematic wave model for the overland flow evaluation and the other C-D layers (subsurface layers) are calculated by the linear storage model [20].

\subsubsection{Watershed Modeling}

The data of digital elevation model (DEM, (SRTM (Shuttle Radar Topography Mission) from USGS internet site is obtained. The resolution of mesh size is $(100 \mathrm{~m})$. By processing the DEM using Global Mapper Program and Golden Surfer software to be input data of Arcview GIS tool, the watershed basin, sub-basin watersheds and stream network determination can be delineated as shown in Figure 3and 4, in addition to obtaining some geomorphologic information such as watershed area, perimeter, and main channel length, etc. We considered some points in the watershed modeling as follow: i) Determination of the watershed boundary location, ii) Division of the watershed into a regular grid of mesh cells $(1 \mathrm{~km})$, iii) Determination of a flow routing network based on mesh cell elevation as given by a DEM and checked against a printed map.

\section{(a) Flow Routing Map}

As well known, there are two types of flow routing system; 4 directions and 8 directions to determine drainage of flow water direction of drainage basin. Hydro-BEAM was originally developed to use a 4-direction flow routing map. The function of a flow routing map is to define a downstream destination for the discharge resulting from every cell in the watershed, with the exception of the furthest downstream mesh cell located at the watershed mouth. Flow direction from any given mesh cell can be estimated using the DEM elevations of the corners of each mesh cell as declared in Fig. 5. Where the flow path of each mesh is decided based on the elevation values of each corner. On the other hand, the perpendicular direction of slope of the two half of the mesh is estimated based on dividing of each mesh into 10 parts. So, the flow direction in each mesh depend on the 
Military Technical College

Kobry El-Kobbah, Cairo, Egypt

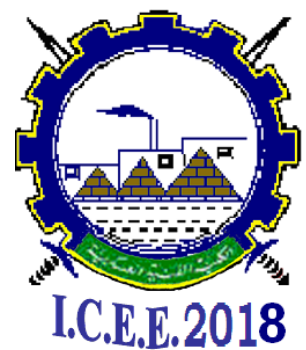

$9^{\text {th }}$ International Conference on

Chemical \& Environmental Engineering

3-5 April 2018

direction of its slope, then manually the opposite and paradox flow directions can be corrected based on the elevation map or the printed topographic map.

\section{(b)Land Use Classification}

Land use information is used to specify the structure of each mesh, its infiltration and runoff characteristics. Hydro-BEAM is set to use five categories of land use types as given in table 2, where they are grouped and represented as a percentage land cover of the total area of the mesh cell.

The land use distribution data of the world, GLCC (Global Land Cover Characterization) are available in USGS internet site. Hydro-BEAM is setting to five land use categories; so land use were reclassified into five categories of land use types as follow; mountains and forests, paddy field (rice field) and field, desert, city or urban areas and Water as given in table 2 . The distribution of urban land use type is limited and it is located only at the downstream part of Wadi El- Assiuti and wadi Qena.

\subsubsection{Climatic Model}

The metrological data are needed for each mesh in hydro-BEAM as input data for the climatic model to calculate evapotranspiration. So, we used climatic data of NCDC (National Climatic Data Center), Global Hourly and Monthly data as shown in table 3.

Due to the lacking of many kind of data, we adopted Thornthwaite method to calculate daily mean potential evapotranspiration (potential evapotranspiration) as given in equations $1,2,3$, and 4 . The mean air temperature and duration of possible sunshine of each mesh are needed as meteorological data for our model.

$$
\begin{aligned}
& E_{p}=0.553 D_{0}\left(10 \frac{T_{i}}{I}\right)^{a} \\
& a=0.000000675 J^{3}-0.0000771 J^{2}+0.01792 J+0.049293 \\
& J=\sum_{I=1}^{12}\left(\frac{T_{i}}{5}\right)^{1.514} \\
& E_{a}=M . E_{p}
\end{aligned}
$$

Where, $E_{a}, E_{p}(\mathrm{~mm} / \mathrm{d})$ are the actual and the potential evapotranspiration; $T i\left({ }^{0} \mathrm{C}\right)$ is the monthly average temperature, $J$ : Heat index, $D_{0}(h / 12 h)$ is the potential day length and $M$ is the reduction coefficient, vapor effective parameter.

\subsubsection{Kinematic Wave Model}

In this paper, Kinematic wave model is applied for surface runoff and stream routing modeling based on the assumption of the river channel cross section is supposed as a triangle shape. A finite difference approximation of the kinematic wave model can be used to model watershed runoff on the surface and layer (A) in Hydro-BEAM. 
Military Technical College Kobry El-Kobbah, Cairo, Egypt

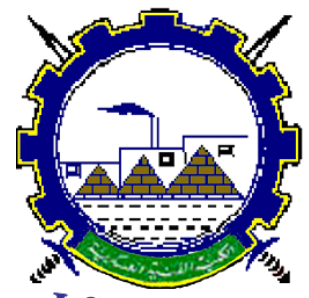

I.C.E.E.2018 $9^{\text {th }}$ International Conference on

Chemical \& Environmental Engineering

3-5 April 2018

$$
\begin{gathered}
\frac{\partial \mathrm{h}}{\partial \mathrm{t}}+\frac{\partial \mathrm{q}}{\partial \mathrm{x}}=\mathrm{r}(\mathrm{x}, \mathrm{t}) \\
\mathrm{q}=\alpha^{\mathrm{m}}
\end{gathered}
$$

Where, $h$ : water depth $m, q$ : is discharge per unit length of flow $\left[\mathrm{m}^{3} / \mathrm{m} . \mathrm{s}\right], r$ is rainfall intensity $[\mathrm{m} / \mathrm{s}], t$ is time [s], $x$ is distance from the upstream edge, and $\alpha, m$ is constant concerning friction.

\subsubsection{Linear Storage Model}

We used linear storage model as given in equations 7 for modeling of groundwater in layers B, C, and D layers in each mesh of the catchment area, thus the ground water storage can be evaluated in our model in Hydro-BEAM.

$$
\frac{\mathrm{ds}}{\mathrm{dt}}=\mathrm{I}-0, \mathrm{O}=\left(\mathrm{k}_{1}+\mathrm{k}_{2}\right) \cdot \mathrm{S}
$$

Where $\mathrm{S}$ : is storage amount $[\mathrm{m}], \mathrm{I}$ : is inflow $\left[\mathrm{ms}^{-1}\right], O$ : is outflow $\left[\mathrm{ms}^{-1}\right], k_{l}, k_{2}$ : are coefficient of permeability.

\subsubsection{Initial and Transmission Losses Model}

Due to the importance of the losses in the arid areas, we added one subroutine to HydroBEAM to calculate the initial and transmission losses in each mesh.

\section{(a) Initial losses}

Initial losses occur in the sub-basins before runoff reaches the stream networks. The (SCS. 1985) method is adopted to calculate initial losses. It has been successfully applied to ephemeral watersheds in SW US, which resemble the eastern desert in Egypt [21]. Runoff in sub basins occurs after rainfall exceeds an initial abstraction $\left(\mathrm{I}_{\mathrm{a}}\right)$ value. Rainfall excess, Q, in NRCS method is related to the effective potential retention value, $S$, as given in equation 10 .

$$
P_{e}=\frac{\left(p-I_{a}\right)^{2}}{\left(p-I_{a}\right)+S}
$$

The initial abstraction is suggested by NRCS to be approximately $20 \%$ of the maximum potential retention value. The initial abstraction consists mainly of interception, infiltration prior to runoff, and surface storage, and is related to potential maximum retention (Empirical relationship of $I_{a}$ and $S$ ) as given in equation 9

$$
I_{\mathrm{a}}=0.2 \mathrm{~S}
$$

$S(\mathrm{~mm})$ is the maximum retention parameter and given as in equation 10 . 


\section{Military Technical College \\ Kobry El-Kobbah, Cairo, Egypt}

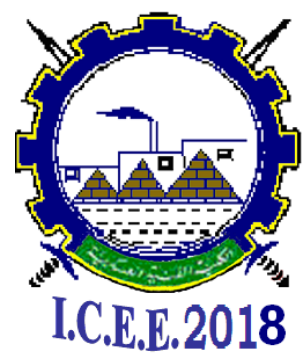

$9^{\text {th }}$ International Conference on

Chemical \& Environmental

Engineering

3-5 April 2018

$$
\mathrm{CN}=\frac{25400}{254+\mathrm{S}}
$$

Where, $P_{e}=$ Accumulated precipitation excess at time $\mathrm{t}(\mathrm{mm}), P=$ Accumulated rainfall depth at time t $(\mathrm{mm}), I_{a}=$ the initial loss $(\mathrm{mm}), S=$ potential maximum retention $(\mathrm{mm})$. The catchment's capability for rainfall abstraction is inversely proportional to the runoff curve number. For $\mathrm{CN}=100$, no abstraction is possible, with runoff being equal to total rainfall. On the other hand, for $\mathrm{CN}=1$ practically all rainfall would be abstracted, with runoff being reduced to zero. The curve number $\mathrm{CN}$ value depends on hydrologic soil group and land use cover complex. The hydrologic soil groups as defined by SCS soil scientists are A, B, C, and D are classified based o the soil type and infiltration rate. So, based on the land use, soil type and infiltration rate, the curve number of the land use in the studied area can be estimated as given in table 4.

\section{(b) Transmission Losses}

Transmission loss is important not only in its obvious effect on flow reduction, but also as a source of ground water recharge. The variables that are considered useful in estimating the variation in the transmission loss included; 1-the flow volume at the upstream end of the reach, 2-channel antecedent condition, 3-chaneel slope, 4- channel bed material, the duration of the flow, 5- channel width. Walter's (1990) developed equation to calculate the transmission losses as given in equation 11.

$$
\mathrm{V}_{1}=0.0275 \mathrm{~V}_{\mathrm{A}}^{0.872}
$$

Where $V_{l}=$ transmission loss for the first mile (acre-ft), $V_{A}=$ upstream flow volume.

\section{The Global Satellite Mapping of Precipitation (GSMaP)}

A key factor affecting the hydraulic behavior of the wadi system is rainfall. Its duration, intensity, distribution, and return periods are major influences. The study area have different physiographic and topographic features. It is well known that, the hydrological modeling for runoff simulation in arid regions does not have enough data. In this research we will use GSMaP data for its feasibility for use to runoff simulation in remote areas as shown in figure 6-7.

The simulation of run-off has been done with $1 \mathrm{~km}$ by $1 \mathrm{~km}$ spatial resolution. GSMaP Product is available in spatial resolution $10 \mathrm{~km}$ by $10 \mathrm{~km}$ only, so, In case of finer resolution as $1 \mathrm{~km}$ by $1 \mathrm{~km}$, it is needed to use downscaling techniques to use these data. The calculation processes are summarized as follows: (1) picking up of GSMaP data of 


\section{Military Technical College \\ Kobry El-Kobbah, Cairo, Egypt}

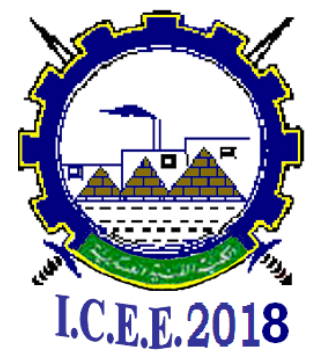

9 $\underline{\text { th }}$ International Conference on

Chemical \& Environmental Engineering

3-5 April 2018

the target basins, (2) determination and delineation of the catchments and setting of modeled mesh spatial resolution, and (3) using Hydro-BEAM for simulation.

\section{Results}

The numerical simulation has been done using the calibrated model of Hydro-BEAM by [20]. A sensitivity analysis of the model parameters have been done to get the optimal solution by trial-error calibration method. Another sensitivity analysis of the model parameters have been done to get the optimal solution by field experiments calibration method [12].The watershed modeling using GIS technique is achieved, surface runoff and stream routing modeling based on using the Kinematic wave approximation is applied, the initial and transmission losses modeling is estimated by using SCS (1985) method (an empirical model for rainfall abstractions suggested by the U.S Soil conservation Service) and Walter's equation (1990) respectively, Groundwater modeling based on the linear storage model is used. A physical-based distributed hydrological model; Hydro-BEAM (Hydrological River Basin Environmental Assessment Model) is used to simulate run-off at wadi El Assiuti and wadi Qena as listed in table 5.

The surface flow discharge can be demonstrated in Wadi El- Assiuti and wadi Qena watershed using the climatic data which extracted from GSMap for the years (2003-2010) for our simulation, where the daily and hourly output results can be obtained using Hydro-BEAM as shown in Figures 8 - 9. However the lacks of observed data, the simulated results of surface runoff were achieved in the target area. It is clear from the results of hourly simulations (simulation period 2003-2010) that they are completely showing specific hydrograph of wadi system, while the curve is steep rising and gentle declining within a short time during the flash flood events.

\section{Conclusion}

Satellite precipitation products provide new kinds of input data (i.e. uninterrupted and global coverage) for various hydrologic models which are very important for regional and global hydrologic prediction and water resources management worldwide. This is especially useful for data-spare and ungauged basins. In the current study, the stream flow simulation utility of one of most widely used high-resolution satellite precipitation products (GSMaP) which were evaluated within the Wadi El- Assiut and wadi Qena, Egypt. By using the climatic data (GSMaP) of the years (2004-2010) the surface flow discharge can be demonstrated in Wadi El- Assiut and wadi Qena, Egypt, for our simulation where the daily and hourly output results can be obtained using Hydro-BEAM 

Military Technical College
Kobry El-Kobbah, Cairo, Egypt

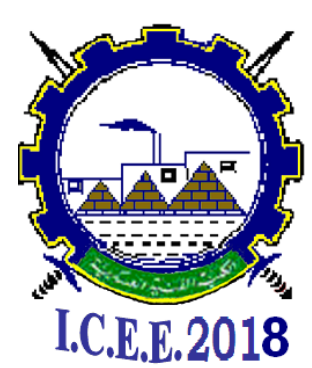

$9^{\text {th }}$ International Conference on

Chemical \& Environmental Engineering

3-5 April 2018

In summary, the current satellite precipitation products have significant potential in hydrological research and applications. The satellite precipitation products for stream flow simulation described in the present work will hopefully be a good reference for future utilizations of various satellite precipitation products in global and regional hydrological applications. This would especially be the case for the data-sparse and ungauged basins.

The runoff simulation is successfully achieved using Hydro-BEAM in the Wadi system. The simulation of hourly discharge also is accomplished. The novelty of this research is that the proposed model shows the discontinuously surface flow of the Wadi system, in addition to the distribution of the equivalent subsurface water storage. The conjunctive use of surface and subsurface water can be used in the real application for the flood control and water resources management

It is concluded that the proposed model is considered an applicable methodology in larger areas and consequently, a vital contribution to estimate the distributed surface and subsurface runoff regionally not only in Wadi El- Assiut and wadi Qena, Egypt but also in the other arid regions. Much more researches is recommended for the Wadi system modeling based on the observed data and the regional application of the Wadi system model is our future target.

In summary, this research is an integrated numerical model based on sporadic precipitation and under conditions of data deficiency where we developed the watershed modeling by using GIS tool, surface runoff and stream routing modeling based on using the Kinematic wave approximation, the initial and transmission losses modeling estimated with applying SCS method (an empirical model for rainfall abstractions suggested by the U.S Soil conservation Service) and Walter's Equation (1990) respectively, and groundwater modeling based on the linear storage model.

Much high quality research is needed, particularly to investigate processes such as spatial rainfall, and infiltration and groundwater recharge from ephemeral flows. New approaches to flood design and management are required which represent the extreme value characteristics of arid areas and recognize the severe problems of conventional rainfall-runoff analysis. One reason for the focus of this paper on the arid, semiarid regions to develop distributed hydrological model to overcome the prescribed struggles for water resources management and flood control purposes, in addition to evaluate the transmission loss and its effect on both surface and subsurface water. 
Military Technical College

Kobry El-Kobbah, Cairo, Egypt

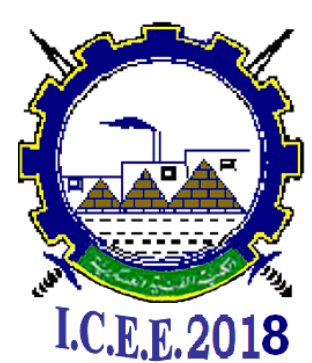

$9^{\text {th }}$ International Conference on

Chemical \& Environmental

Engineering

3-5 April 2018

\section{References}

[1] K.Okamoto, T.Iguchi, N.Takahashi, K. Iwanami, and T. Ushio, (2005) The Global Satellite Mapping of Precipitation (GSMaP) Project. 25 th International Geoscience and Remote Sensing Symposium, Seoul, IEEE, 25-29 July 2005, 3414-3416

[2] K. Aonashi, J.Awaka, M.Hirose, T.Kozu, T.Kubota, G.Liu, S.Shige, S.Siga, S.Seto, N. Takahashi, and Y.N. Takayabu, (2009) GSMaP Passive Microwave Precipitation Retrieval Algorithm: Algorithm Description and Validation. Journal of Applied Meteorology, 87A, 119-136.

[3] T. Kubota, S.Shige, H.Hanshizume, K.Aonashi, N.Takahashi, S.Seto, Y.N.Takayabu, T.Ushio, K.Nakagawa, K.Iwanami, M. Kachi, and K. Okamoto, (2007) Global Precipitation Map Using Satellite-Borne Microwave Radiometers by the GSMaP Project: Production and Validation. IEEE Transactions Geoscience Remote Sensing, 45, 2259-2275. https://doi.org/10.1109/TGRS.2007.895337

[4] T. Kubota, T.Ushio, S.Shige, S.Kida, M. Kachi, and K. Okamoto, (2009) Verification of High Resolution Satellite-Based Rainfall Estimates around Japan Using a Gauge Calibrated Ground Radar Data Set. Journal of Meteorological Society of Japan, 87A, 203-222. https://doi.org/10.2151/imsi.87A.203

[5] S. Seto, (2009) An Evaluation of Overland Rain Rate Estimates by the GSMaP and GPROF Algorithm: The Role of Lower Frequency Channels. Journal of Meteorological Society, 67, 183-202. https://doi.org/10.2151/imsi.87A.183

[6] K. Fukami, Y.Shirashi, H. Inomata, and G. Ozawa, (2010) Development of Integrated Flood Analysis System (IFAS) Using Satellite-Based Rainfall Products with a Self-Correction Method. International Centre for Water Hazard and Risk Management under Auspices of UNESCO (ICHARM), Public Works Research Institute, Tsukuba.

[7] M.S.Shrestha, K.Takara, T. Kubota, and S.R. Bajracharya, (2011) Verification of GSMaP Rainfall Estimates over the Central Himalayas. Journal of Japan Society of Civil Engineers, 67, I_37-I_42. https://doi.org/10.2208/isceihe.67.i 37

[8] M.D.Setiawati, F. Miura, and P. Aryastana, (2013) Verification of Hourly GSMaP Rainfall Estimates during the Flood Events in Kumamoto Prefecture. Bali.

[9] T.Dinku, F.Ruiz, S. Connor, and P. Ceccato, (2009) Validation and Inter comparison of Satellite Rainfall Estimates over Colombia. Journal of Applied Meteorology and Climatology 49, 1004-1014. https://doi.org/10.1175/2009TAMC2260.1

[10] T.Ushio, K.Sasashige, T.Kubota, S.Shige, K. Okamoto, and K. Aonashi, (2009) A Kalman Filter Approach to the Global Satellite Mapping of Precipitation (GSMaP) from Combined Passive Microwave and Infrared Radiometric Data. Journal of 
Military Technical College

Kobry El-Kobbah, Cairo, Egypt

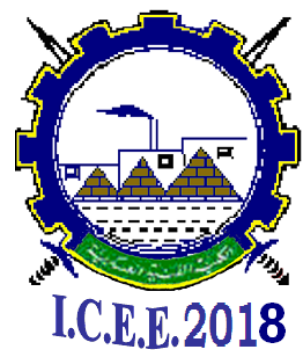

$9^{\text {th }}$ International Conference on

Chemical \& Environmental Engineering

3-5 April 2018

Meteorological Society ofJapan, 87A, 137-151. https://doi.org/10.2151/imsi.87A.137

[11] S. Liang, X. Li, and J. Wang, (2012) Advanced Remote Sensing: Terrestrial Information Extraction and Applications. Academic Press, Oxford.

[12] A. Bakheet (2015) Hydrological Modeling of Surface and Subsurface Water at Wadi El Assiuti, Assiut, Egypt. M.Sc. Thesis, Fac. Sci. Assiut Univ.

[13] T.Kojiri T.Hamaguchi and M. Ode (2008) Assessment of global warming impacts on water resources and ecology of river basin in Japan, J. of Hydro-envirnment research, Elsevier, vol. 1, pp. 164-175

[14] Y.Sato , X.Y Ma. , J.Q. Xu, M. Matsuoka, H.X. Zheng, C.M. Liu and Y. Fukushima (2008) Analysis of long-term water balance in the source area of the Yellow River basin, Hydrological Processes 22, pp.1618-1629, (2008).

[15] T. Kojiri (2006) Hydrological River Basin Assessment Model (Hydro-BEAM). In Singh V.P. and Frevent D.K., "Watershed models", Taylor \& Francis, CRC Press, Boca Raton, Florida, pp. 613-626,

[16] T. Kojiri, A. Tokai and Y. Kinai (1998) Assessment of river basin environment through simulation with water quality and quantity. Annuals of Disaster Prevention Research Institute, Kyoto University, No. 41 B-2, pp. 119-134 (in Japanese).

[17] J. Park, , T. Kojiri, , S. Ikebuchi, , and S. Oishi, (2000): GIS based hydrological comparison and run-off simulation of a river basin. Fresh Perspectives on Hydrology and Water Resources in Southeast Asia and the Pacific, Mosley, M. P. (eds.), Christchurch, 143-156.

[18] N. Tamura, and T. Kojiri, (2002): Water quantity and turbidity simulation with distributed runoff model in the Yellow River basin. Flood Defence '2002, Wu et al. (eds.), Science Press, New York Ltd., Vol. 2, 1699-1705

[19] A. Tokai, , T. Kojiri, , and H. Yoshikawa, (2002): Case study of basin wide environmental quality assessment based on the distributed runoff model. 6th Water Resources Symposium, Japan, 229-234 (in Japanese).

[20]M. Saber (2010) Hydrological approaches of Wadi system considering flash floods in arid regions," Ph.D. thesis, Kyoto University, 2010.

[21] W.R. Osterkamp, L.J. Lane and C.S Savard (1994): Recharge estimates using a Geomorphic / distributed parameter simulation approach, Amargosa river basin. Water Resources Bulletin, American Water Resources Association, 30, 3, pp. 493507. 
Military Technical College Kobry El-Kobbah, Cairo, Egypt

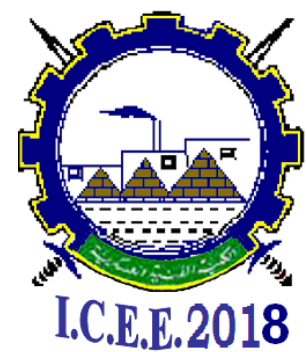

$9^{\text {th }}$ International Conference on

Chemical \& Environmental Engineering

3-5 April 2018

Table1. Characteristic of GSMaP

\begin{tabular}{|c|c|c|c|}
\hline & $\begin{array}{c}\text { GSMaP_MVK+, } \\
\text { GSMaP_MVK. }\end{array}$ & GSMaP_MW & GSMaP_NRT \\
\hline Temporal resolution & Hourly, daily & Hourly, daily & Hourly, daily \\
\hline spatial resolution & $0.1 \times 0.1$ lat/lon & $0.25 \times 0.25$ lat/lon & $0.1 \times 0.1$ lat/lon \\
\hline Coverage & $60 \mathrm{~N}$ to $60 \mathrm{~S}$. & $60 \mathrm{~N}$ to $60 \mathrm{~S}$. & $60 \mathrm{~N}$ to $60 \mathrm{~S}$. \\
\hline Grid & $3600 \times 1200$ pixels & $1440 \times 480$ pixels & \\
\hline
\end{tabular}

Table2. Land use types of modified Hydro-BEAM [20]

\begin{tabular}{|c|c|}
\hline Category & Description \\
\hline Mountains & Densely-vegetated regions (forest) \\
\hline Field+ Paddy field & Agricultural regions including farms and orchards \\
\hline Desert & Most of the Wadi areas are desert in the arid areas \\
\hline Urban area & Paved or otherwise impervious urban regions \\
\hline Water body & Bodies of water including inland waters \\
\hline
\end{tabular}

Table3. Types of input data and its resources [20]

\begin{tabular}{|c|c|}
\hline Type of data & Source of the data \\
\hline $\begin{array}{c}\text { DEM Data; SRTM (Shuttle Radar } \\
\text { Topography Mission) }\end{array}$ & $\begin{array}{c}\text { CGIAR-CSI (Consortium for Spatial } \\
\text { Information) }\end{array}$ \\
\hline $\begin{array}{c}\text { Land use; GLCC (Global Land Cover } \\
\text { Characterization) }\end{array}$ & USGS(U.S. Geological Survey) \\
\hline $\begin{array}{c}\text { Climatic Data; Surface Data Hourly Global } \\
\text { data }\end{array}$ & NCDC(National Climatic Data Center) \\
\hline $\begin{array}{c}\text { Daily Climatic quality Data; GHCN } \\
\text { (Global Historical Climate Network Ver.2) })\end{array}$ & NCDC(National Climatic Data Center) \\
\hline
\end{tabular}




\begin{tabular}{|l|c|}
\hline Proceeding of the $9^{\text {th }}$ ICEE Conference 3-5 April 2018 & EPC \\
\hline
\end{tabular}

Military Technical College

Kobry El-Kobbah,

Cairo, Egypt

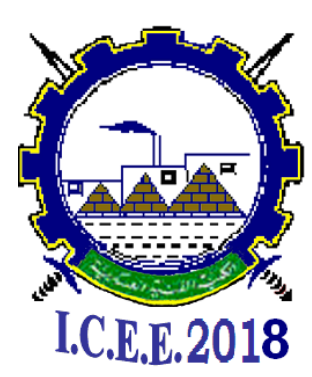

Table 4 Curve number values of the land use type

\begin{tabular}{|c|c|c|c|}
\hline Land use & Soil type & Soil group & Curve number \\
\hline Forests & N/A & A & 45 \\
\hline Field & N/A & B & 71 \\
\hline Desert & N/A & A & 63 \\
\hline Urban & N/A & B & 86 \\
\hline \multirow{2}{*}{ Desert } & limestone & N/A & 98 \\
\cline { 2 - 4 } & Wadi deposite & N/A & 63 \\
\hline
\end{tabular}

Table 5 results

\begin{tabular}{|c|c|c|}
\hline year & $\begin{array}{c}\text { Peak of Discharge }\left(\mathrm{m}^{3} / \mathrm{s}\right) \\
\text { Wadi El Assiuti }\end{array}$ & $\begin{array}{c}\text { Peak of Discharge }\left(\mathrm{m}^{3} / \mathrm{s}\right) \\
\text { Wadi Qena }\end{array}$ \\
\hline $1 / 2004$ & 36.6 & 88.29 \\
\hline $1 / 2006$ & 1.66705 & 1.6 \\
\hline $1 / 2007$ & 3.13853 & 14.13 \\
\hline $1 / 2008$ & 1.65229 & 825 \\
\hline $1 / 2010$ & 183.28 & 603 \\
\hline
\end{tabular}


Military Technical College

Kobry El-Kobbah,

Cairo, Egypt

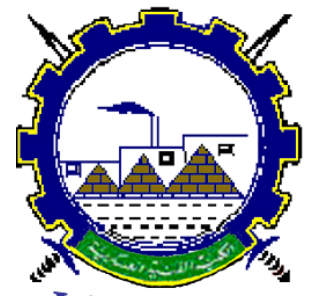

I.C.E.E.2018 $9^{\text {th }}$ International Conference on

Chemical \& Environmental

Engineering

3-5 April 2018

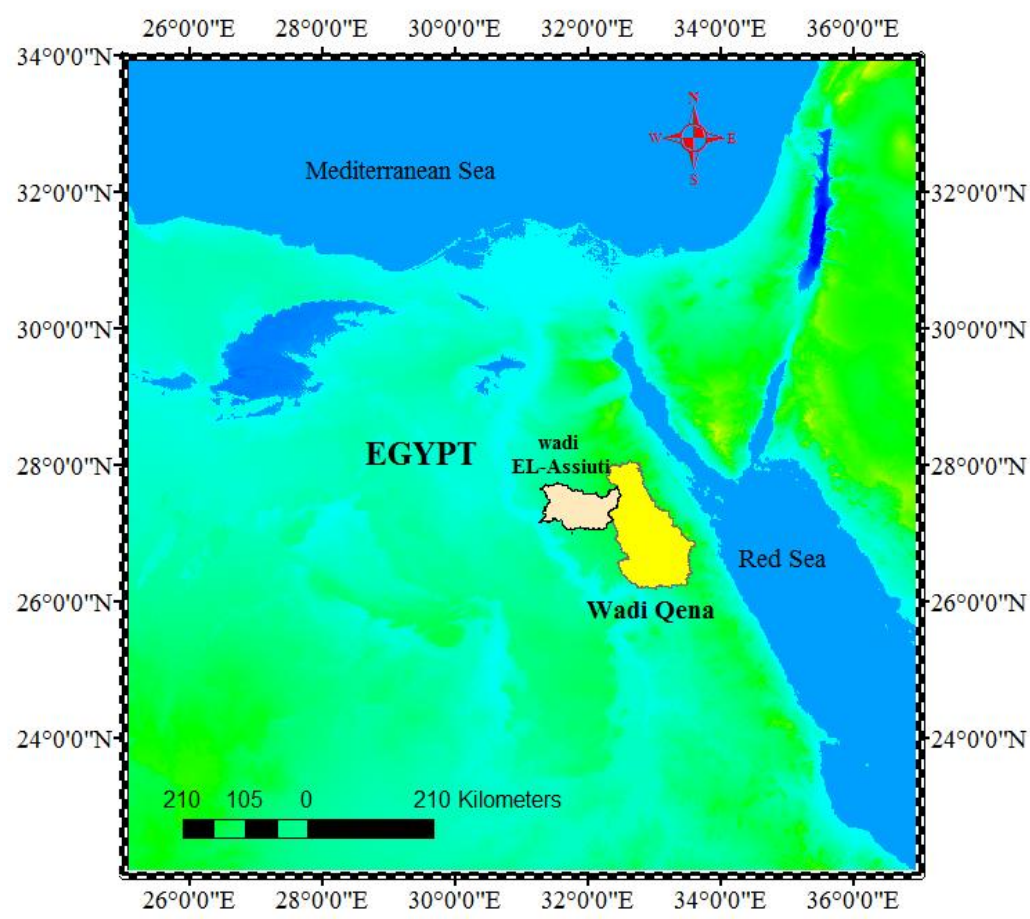

Figure 1 location map of wadi El-Assiuti and wadi Qena

A layer $0.255 \mathrm{~m}$ thickness

B layer $2.5 \mathrm{~m}$ tkickness

C layer $3.5 \mathrm{~m}$ thickness

D layer $10 \mathrm{~m}$ thickness

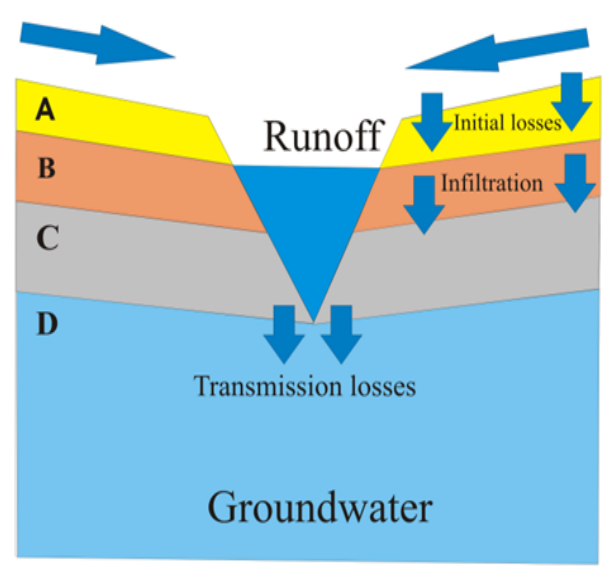

Figure 2 Conceptual representation of Hydro-BEAM (after [13], [12]) 
Military Technical College Kobry El-Kobbah, Cairo, Egypt

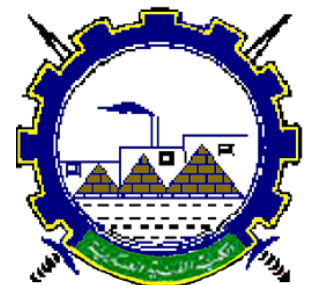

I.C.E.E.2018 $9^{\text {th }}$ International Conference on

Chemical \& Environmental

Engineering

3-5 April 2018
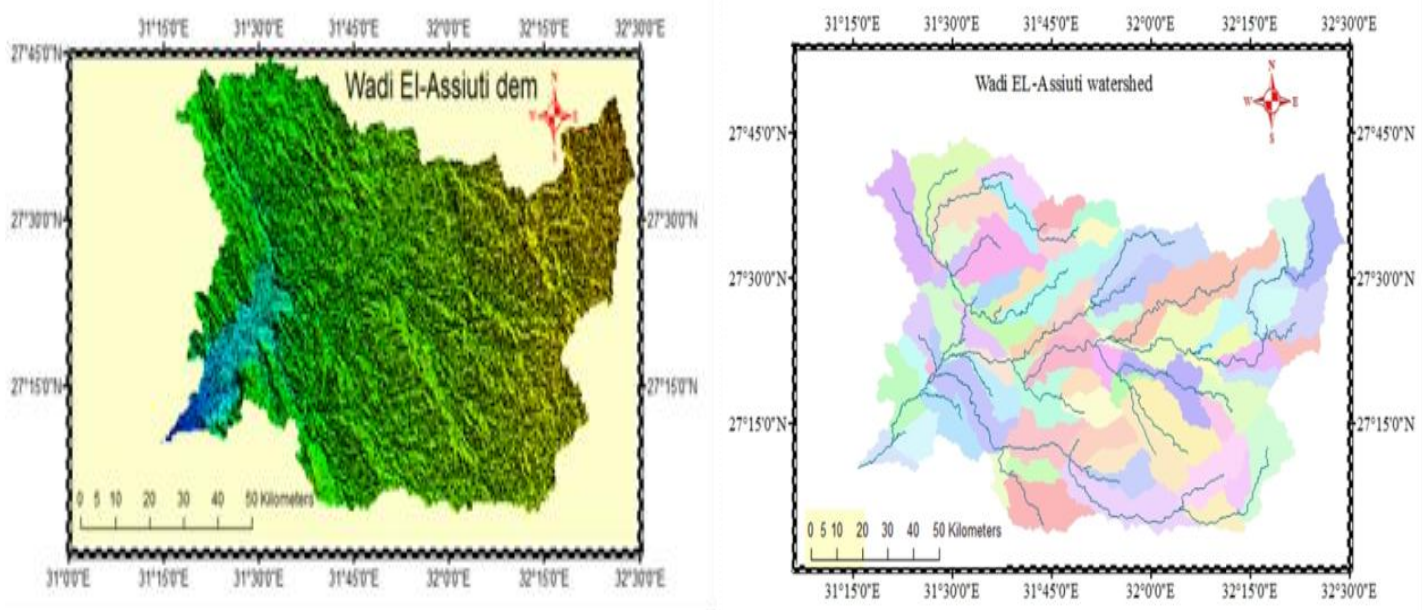

Figure 3 Dem, Watershed delineation and stream network determination of wadi ElAssiuti.
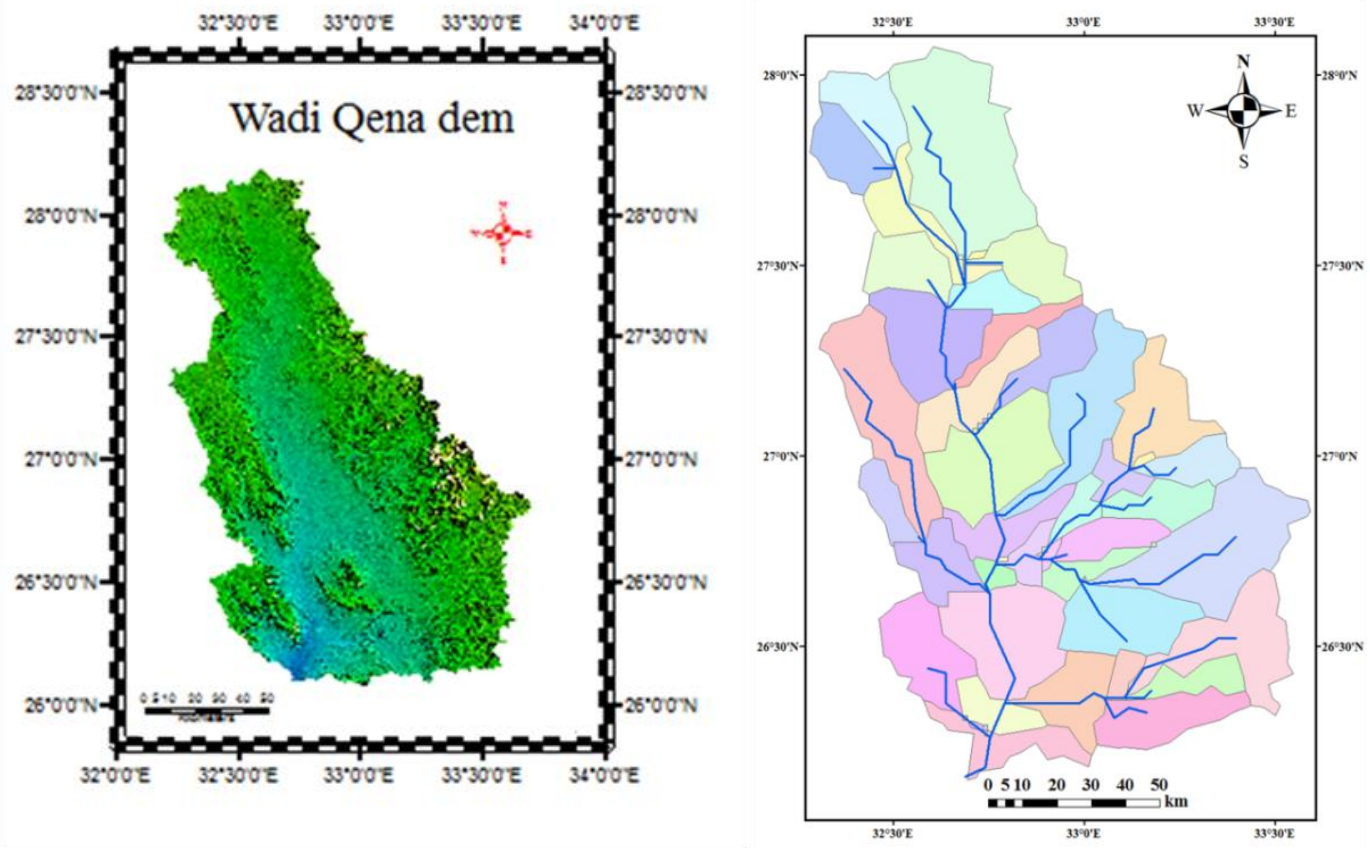

Figure 4 Dem, Watershed delineation and stream network determination of wadi Qena. 
Military Technical College Kobry El-Kobbah, Cairo, Egypt

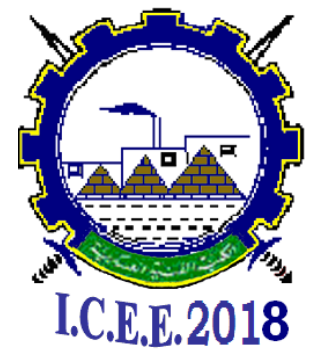

$9^{\text {th }}$ International Conference on

Chemical \& Environmental Engineering

3-5 April 2018
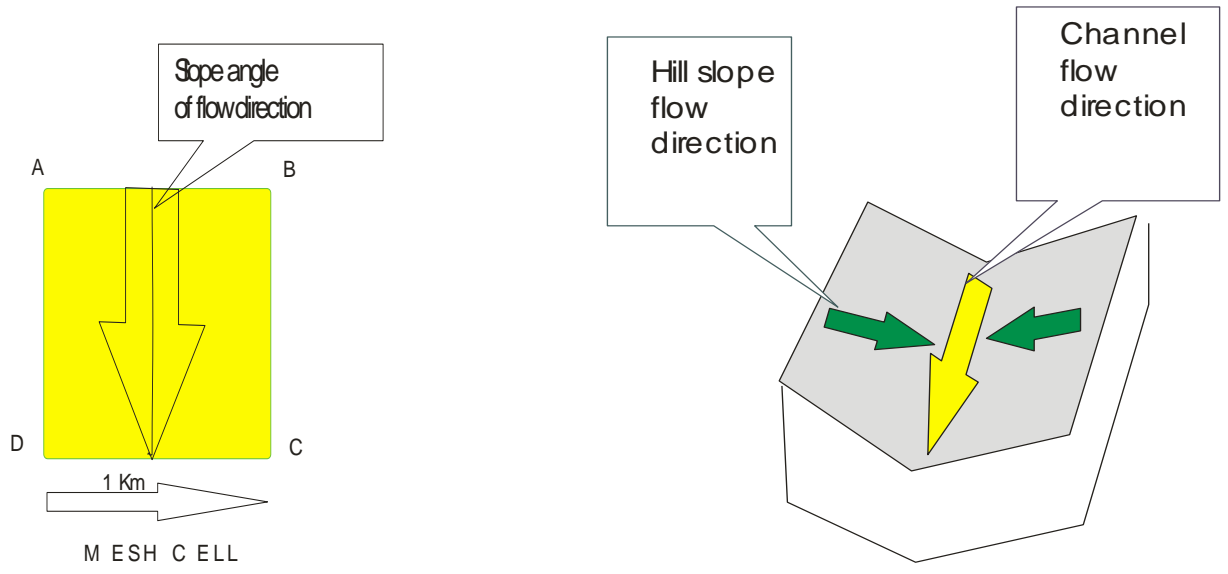

Figure 5 Schematic diagram of the flow direction determination
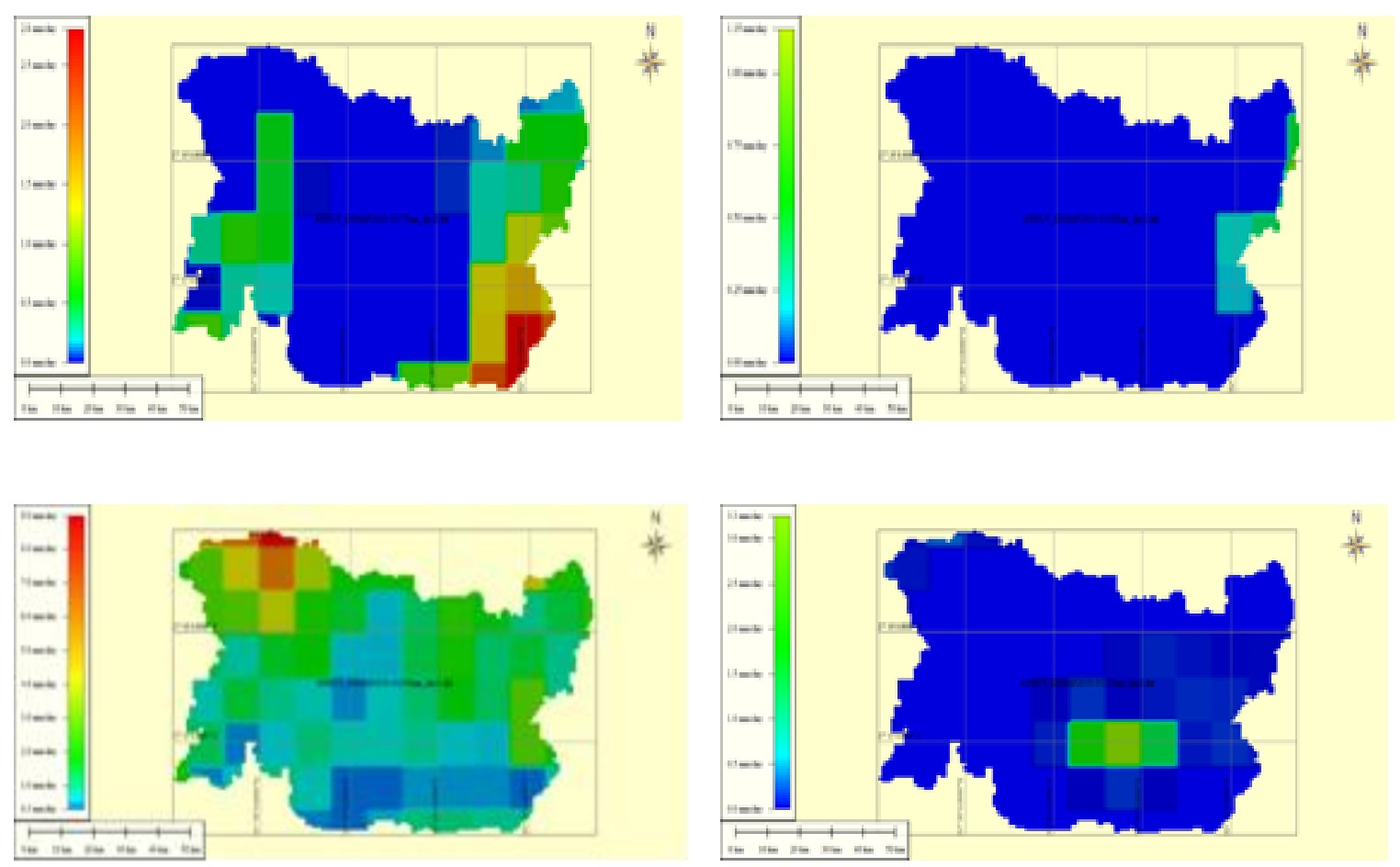

Figure 6 Distribution maps of the rainfall data from GSMaP showing the event of January 2010 (days 17, 18,30 and 31) wadi El-Assiuti 
Military Technical College

Kobry El-Kobbah,

Cairo, Egypt

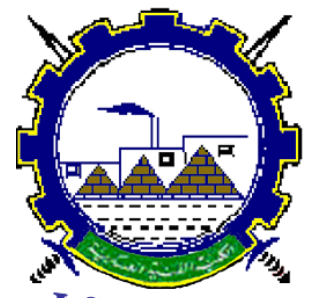

I.C.E.E.2018 $9^{\text {th }}$ International Conference on

Chemical \& Environmental

Engineering

3-5 April 2018
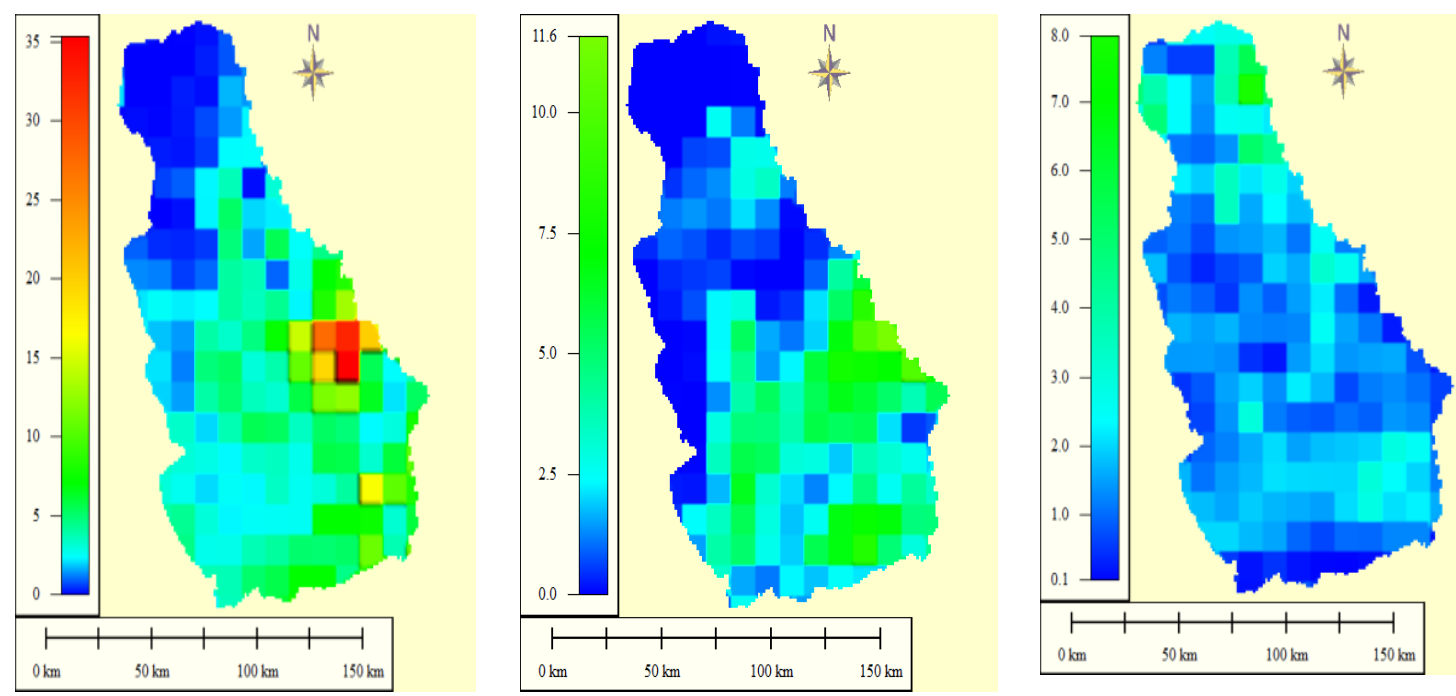

Figure 7 Distribution maps of the rainfall data from GSMaP showing the event of January 2010 (days 17, 18 and 30) wadi qena 
Military Technical College Kobry El-Kobbah, Cairo, Egypt

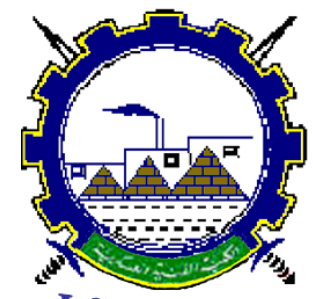

I.C.E.E.2018 $9^{\text {th }}$ International Conference on

Chemical \& Environmental

Engineering

3-5 April 2018
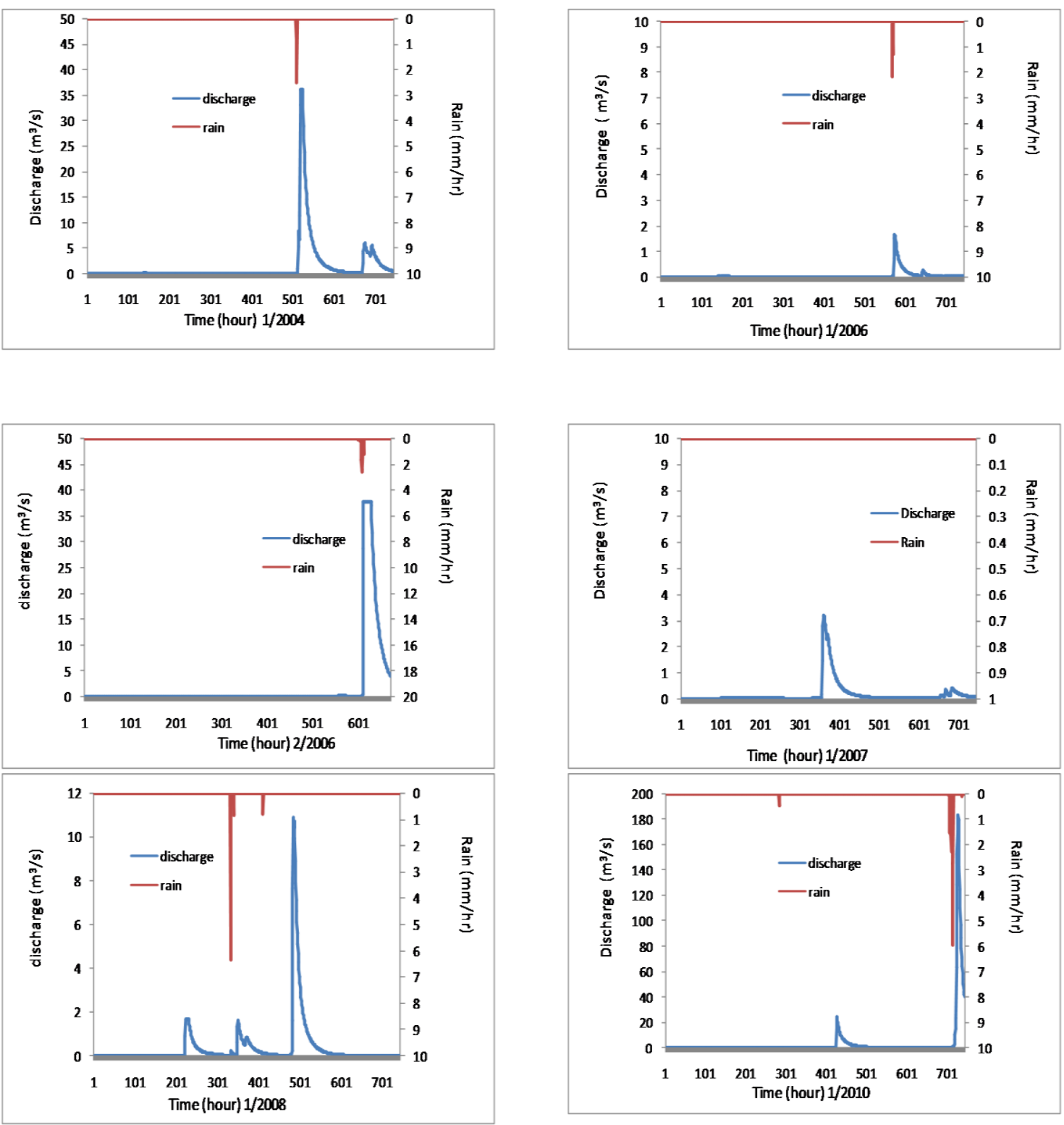

Figure 8 Hourly discharge simulation hydrograph and rainfall hyetograph in Wadi El-Assiuti 
Military Technical College Kobry El-Kobbah, Cairo, Egypt

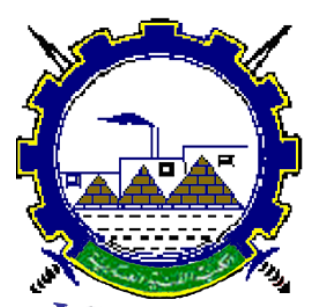

I.C.E.E.2018 $9^{\text {th }}$ International Conference on

Chemical \& Environmental

Engineering

3-5 April 2018
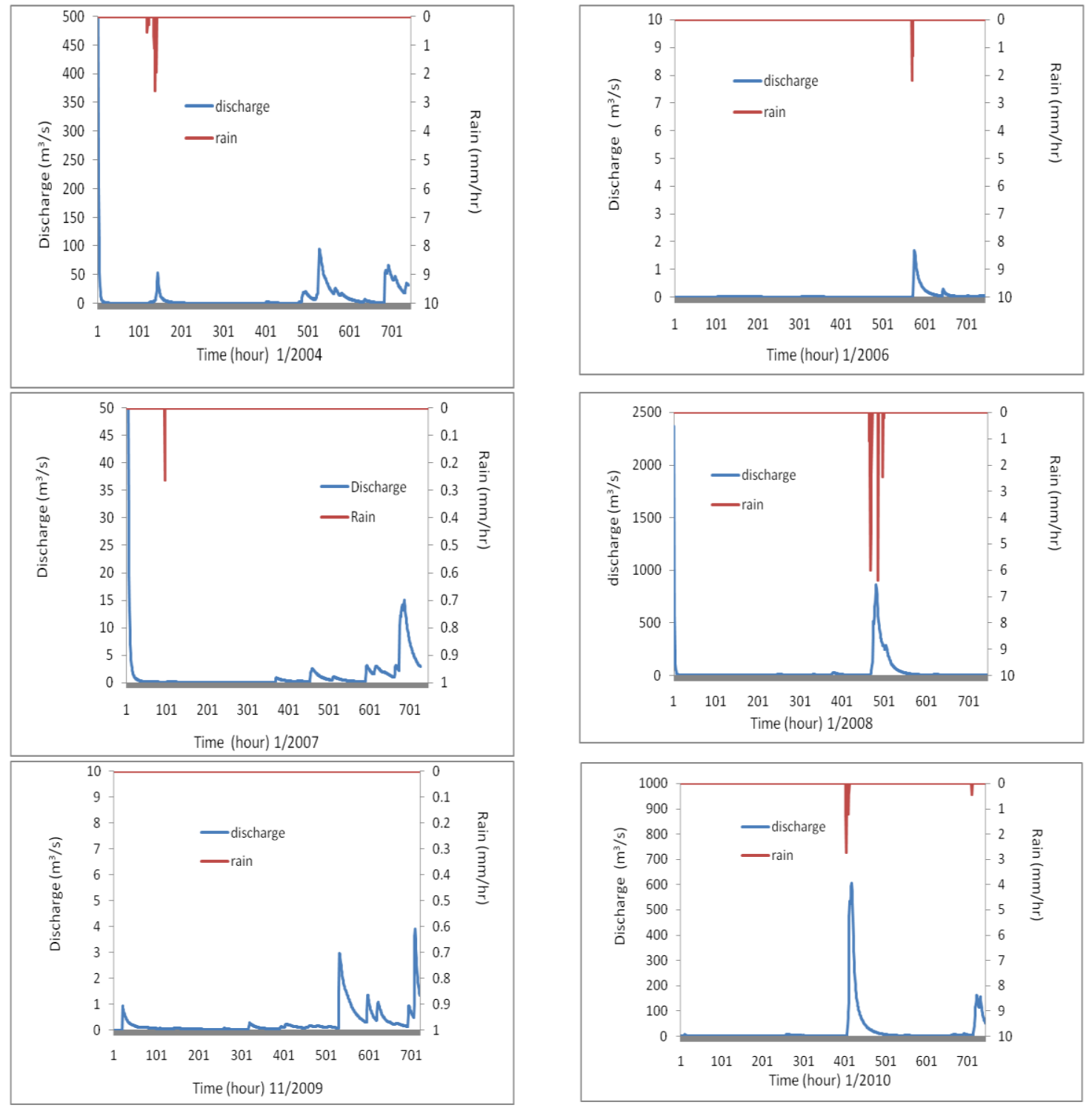

Figure 9 Hourly discharge simulation hydrograph and rainfall hyetograph in Wadi Qena 